\title{
STUDIES IN IRON TRANSPORTATION AND METABOLISM. III. THE NORMAL FLUCTUATIONS OF SERUM AND \\ "EASILY SPLIT-OFF" BLOOD IRON IN INDIVIDUAL SUBJECTS
}

\author{
By CARL V. MOORE, VIRGINIA MINNICH, AND JO WELCH \\ (From the Department of Medicine, Division of Research Medicine and the Ohio Agricultural \\ Experiment Station, Division of Home Economics, Ohio State University, Columbus)
}

(Received for publication April 22, 1939)

Recent studies have directed attention to the great theoretical and practical significance of serum or plasma iron. It has been demonstrated, in the first place, that plasma iron is of metabolic importance in that it serves as the medium for iron transportation in the mammalian organism $(2,3,4,5)$. This concept has made possible a more direct approach to the analysis of the factors controlling iron absorption since an index of the amount of iron being absorbed from the intestinal tract under standard conditions can be gained by measuring increases in plasma iron $(2,6,7)$. In the second place, the differences which occur in fasting plasma iron values in various of the anemic states have been shown to be of differential diagnostic value $(2,4,5$, $8,9)$, and of importance in permitting one to interpret the adequacy of iron reserves, rates of erythrocytogenesis, and rates of red blood cell destruction $(2,3)$.

These several uses to which a study of plasma iron can be applied are dependent upon a thorough knowledge of the fluctuations which may occur in any given individual under normal circumstances. Present information as to the normal range for plasma iron values in the human has been obtained largely from single determinations on a relatively large group of individuals $(4,8,9$; for bibliography prior to 1937 , see reference 1 ). Only a relatively few studies of the variations which occur in the same normal subject from hour to hour or from week to week have been made. Locke, Main, and Rosbash (10) noted that the extension of a fasting interval from 12 to 24 hours was attended, in normal individuals, by a 20 to 40 per cent increase in the serum iron level. Heilmeyer and Plötner (4) obtained variations of plus or minus 30 per cent in the serum iron values of normal persons when determinations were made at intervals of a few hours or of from 1 to 9 days. Thoenes and Aschaffenburg (11) reported the changes which occurred in serum iron in several healthy infants from the age of 20 days to $81 / 2$ months, but these figures are of little value for comparison with those from adult human subjects. The same objection applies to those few additional studies which have been made on the daily and weekly variations in the serum iron values of laboratory animals. The present study was undertaken in an attempt to define more sharply the serum or plasma iron fluctuations which occur in hematologically equilibrated subjects and to determine the effect of antianemic therapy on the blood iron relationships of normal individuals.

Interpretation of the metabolic significance of " easily split-off" blood iron has been altered by Barkan and Schales' (12) recent observations which tend to show that this form of blood iron is probably dissociated by the action of dilute acids from a pseudo-hemoglobin, an intermediary compound formed during the breakdown of hemoglobin into bile pigment. The previous contention that "easily split-off" blood iron is directly related to the function of iron transportation has been withdrawn. The normal variations in "easily split-off" iron values, therefore, are of less importance to a study of this kind; they have been determined, however, and, for the sake of completeness, are included in the presentation.

\section{Methods and spectrophotometric analysis of the intensity of the iron thiocyanate color}

Blood specimens were collected and analyses performed in the manner previously described (1). However, since the accuracy of the iron thiocyanate colorimetric method continues to be 
challenged on the ground that the color extracted from acid solution by iso-amyl alcohol is not constant, not directly proportional to the concentration of iron present, and is sensitive to minor fluctuations in acidity (13), it was decided to iron per $20 \mathrm{cc}$. of solution) were prepared which ranged in acidity from 0.5 to 7 normal with respect to sulphuric acid. The ferric state of ionization was assured by the addition of a few drops of concentrated nitric acid to the solutions at

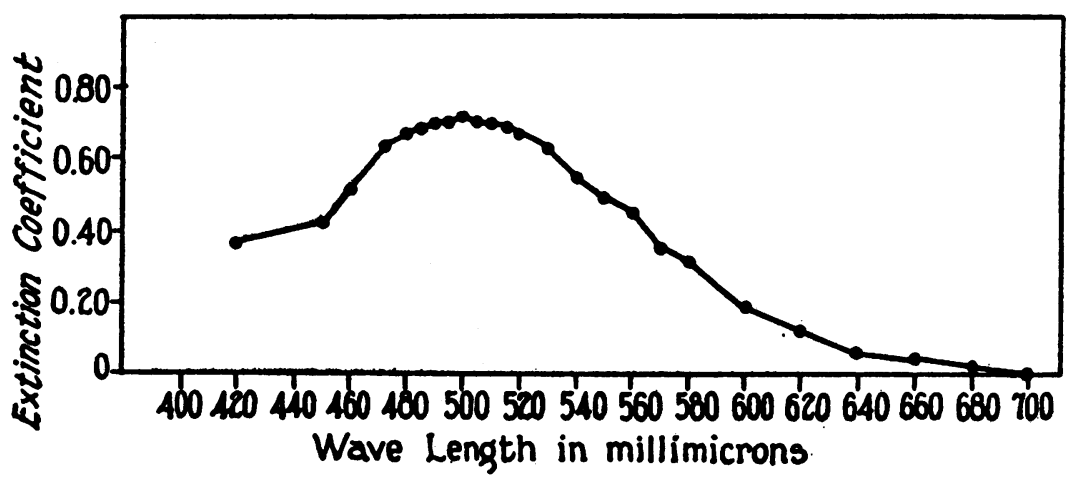

Fig. 1. Absorption Band of Ferric Thiocyanate in Iso-amyz Alcomol

( $0.012 \mathrm{mgm}$. Fe $\mathrm{Fe}^{+++}$in $10 \mathrm{cc}$. iso-amyl alcohol, cell depth $25 \mathrm{~mm}$.)

Extinction Coefficient $=\log \frac{I_{0}}{I}$.

Where: $I_{0}$ is equal to intensity of incident light.

$I$ is equal to intensity of transmitted light.

check the intensity of the color produced under varying conditions with spectrophotometric readings.

The absorption band of ferric thiocyanate in iso-amyl alcohol solution is given in Figure 1; it is apparent that maximum intensity of the band was reached at a wavelength of 500 millimicrons. In order to test the effect of changes in acidity on the intensity of color, standard aqueous solutions of ferric iron $(0.008 \mathrm{mgm}$. of approximately $100^{\circ} \mathrm{C}$. (1). After they had been cooled to room temperature, the solutions were overlaid with $10 \mathrm{cc}$. of iso-amyl alcohol, the color of ferric thiocyanate developed by the addition of 5 cc. of a 20 per cent aqueous solution of potassium thiocyanate, and the color immediately extracted by the alcohol. The intensity of the absorption band at a wavelength of 500 millimicrons was determined for all the solutions and found to be remarkably constant (Figure 2).

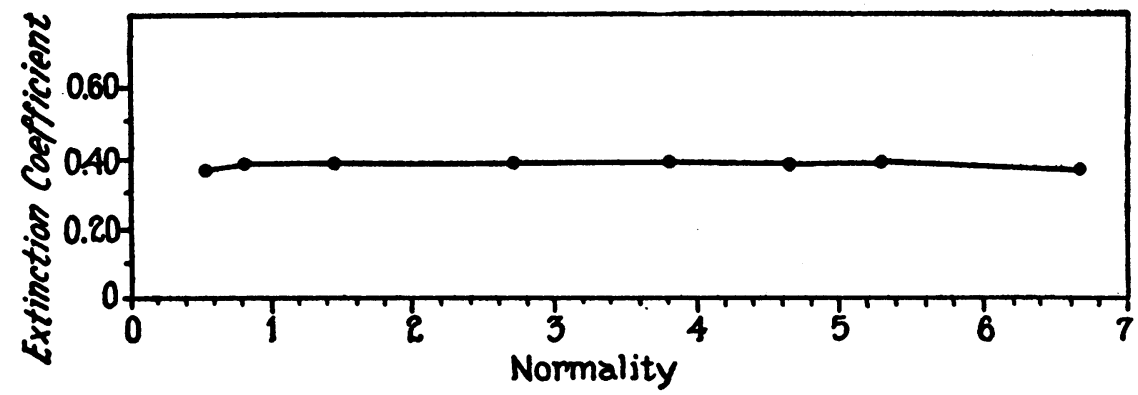

Fig. 2. Efrect of Acidity on Intensity of the Color of Fe(CNS), in Iso-AmyL ALCOHOL-SPECTROPHOTOMETRIC COMPARISONS

Normality refers to the iron solution from which the $\mathrm{Fe}(\mathrm{CNS})$, was extracted by iso-amyl alcohol; $20 \mathrm{cc}$. iron solution $(0.008 \mathrm{mgm}$. Fe) and $10 \mathrm{cc}$. iso-amyl alcohol were used. Normality variation was effected by changing the amount of sulphuric acid. Readings were made at a cell depth of $20 \mathrm{~mm}$., wavelength 500 millimicrons. 
Furthermore, the point of maximum intensity of the band did not shift appreciably from the 500 millimicron wavelength mark, a fact which indicates that the quality of the thiocyanate color remained approximately unchanged. The acidity variations attained here far exceed the 2 to 4 normality range actually encountered in serum iron determinations as done in these investigations (1). Further weight is thus added to the contention that no more accurate control of from acid solution (normality limits as above described) by iso-amyl alcohol was directly proportional to the concentration of iron. Again, the maximum intensity of the absorption band remained relatively constant at $\mathbf{5 0 0}$ millimicrons wavelength.

It was further ascertained that the ferric thiocyanate color in iso-amyl alcohol solution remained practically constant in a darkened room for at least one hour. If the solutions were ex-

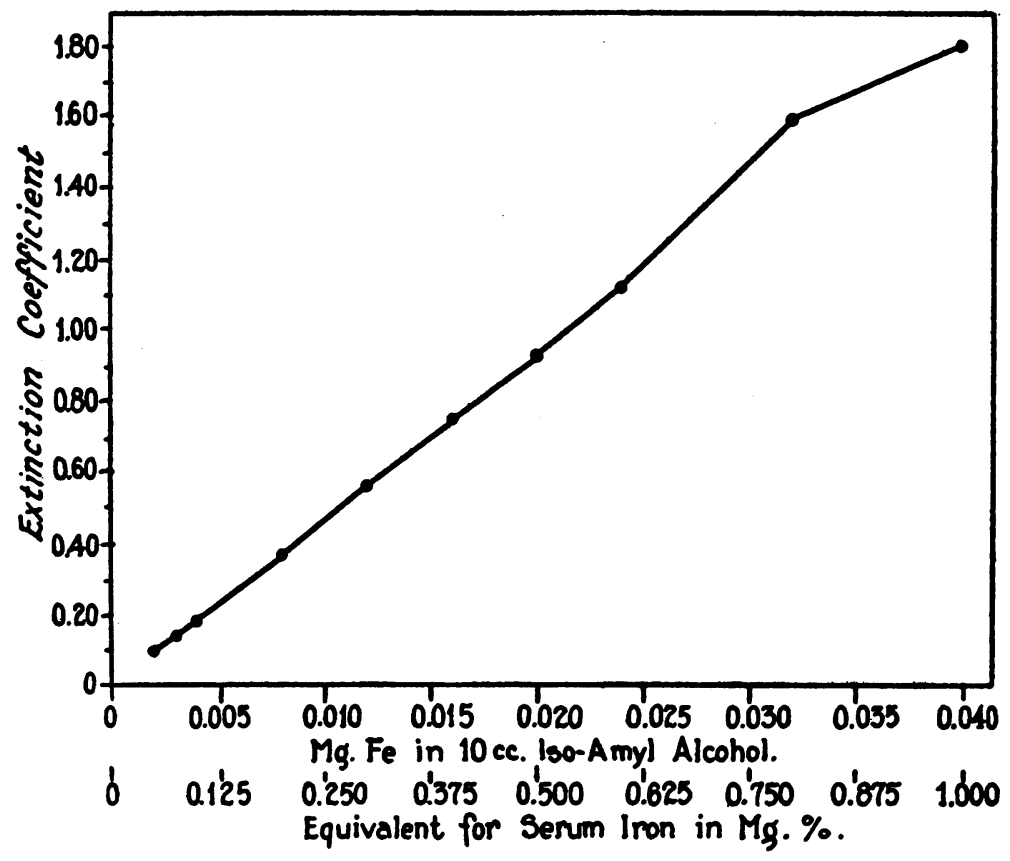

Fig. 3. SPECtrophotometric Comparison of the Intensity of the $\mathrm{Fe}(\mathrm{CNS})$, Color in Iso-Amyl Alcohol Produced by Different Amounts or $\mathrm{Fe}^{+++}$.

Readings made at cell depth $20 \mathrm{~mm}$, wavelength 500 millimicrons.

acidity than this is necessary to insure the accuracy of the method.

Solutions of iron were then prepared to correspond to serum iron variations from 0.05 to $1.0 \mathrm{mgm}$. per cent $(0.002$ to $0.04 \mathrm{mgm}$. of iron in $20 \mathrm{cc}$. of solution to be extracted by the 10 cc. of iso-amyl alcohol). The extinction coefficients of these specimens were measured at a wavelength of 500 millimicrons and plotted on a graph (Figure 3). Within the limits of error of the visual readings, the curve described by the intensity values of the color was a straight line, indicating that for the concentrations of iron used, the color of ferric thiocyanate extracted posed to direct sunlight or to strong artificial light, however, considerable fading occurred during a 60-minute period.

The authors wish to confirm the observation of Barkan, Heilmeyer, Baer, and others that if serum is diluted with one or two volumes of 0.1 N HCL and permitted to stand at room temperature for 15 to 30 minutes before trichloracetic acid is added, the iron is ionized or so changed that it passes quantitatively into the filtrate and is not brought down with the protein-trichloracetic acid precipitate. The use of this method of precipitation frees the serum of any hemoglobin and makes it unnecessary to use the more 
difficult benzidine method of measuring traces of hemoglobin.

Total red blood cell counts were made on blood obtained by finger puncture. The counting chambers and Trenner diluting pipettes used were certified by the U. S. Bureau of Standards. Hemoglobin determinations were done by the acid hematin method with a Duboscq colorimeter and the Newcomer standard color disc. Wintrobe tubes were used for the estimation of packed cell volume; the anticoagulent used was a mixture of a 24-hour period on a number of normal subjects and hospital patients. The fluctuations were relatively slight: 20 to 35 micrograms per $100 \mathrm{cc}$. in serum iron values and 15 per cent in the " easily split-off" iron levels. On one of the subjects, V.M., a young woman aged 28 years, 2 sets of observations at intervals of 1 week were obtained (Figure 4). During the first period, a change of 35 micrograms per cent in serum iron was observed, but during the second period, the amount remained practically constant. Figure 5

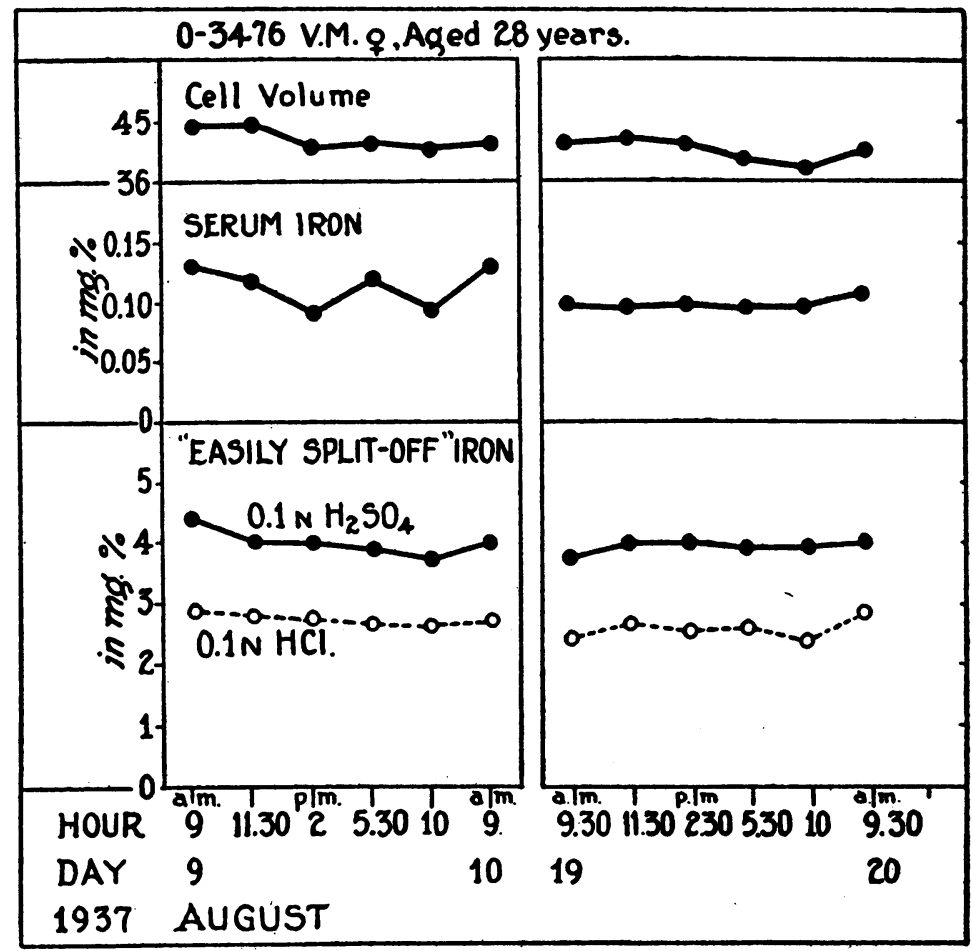

Fig. 4. Variations in Serum and “Easily Split-off” Iron in a Normal Subject during Two 24-hour Periods

ammonium oxalate and potassium oxalate, as recommended by Heller and Paul (14); the specimens were centrifuged at 3,000 r.p.m. for $30 \mathrm{~min}$ utes.

Intra diem variations in serum and "easily splitoff "blood iron

In order to study the quantitative variations which occur in the various blood iron fractions during the daily cycle, we made determinations on 6 or 7 blood samples taken at intervals throughout records the fluctuation of serum and " easily splitoff " blood iron during 24 hours in a white male, aged 55 years, who was a patient in the University Hospital with a diagnosis of chronic alcoholism, portal cirrhosis, and a functional achlorhydria. The values were remarkably constant: It should be noted that the serum iron level in this patient was below the zonal range usually found in adult males; and that a moderate anemia was present. The changes observed in all subjects were not constant in direction, but oscillated and were independent of normal food intake. 


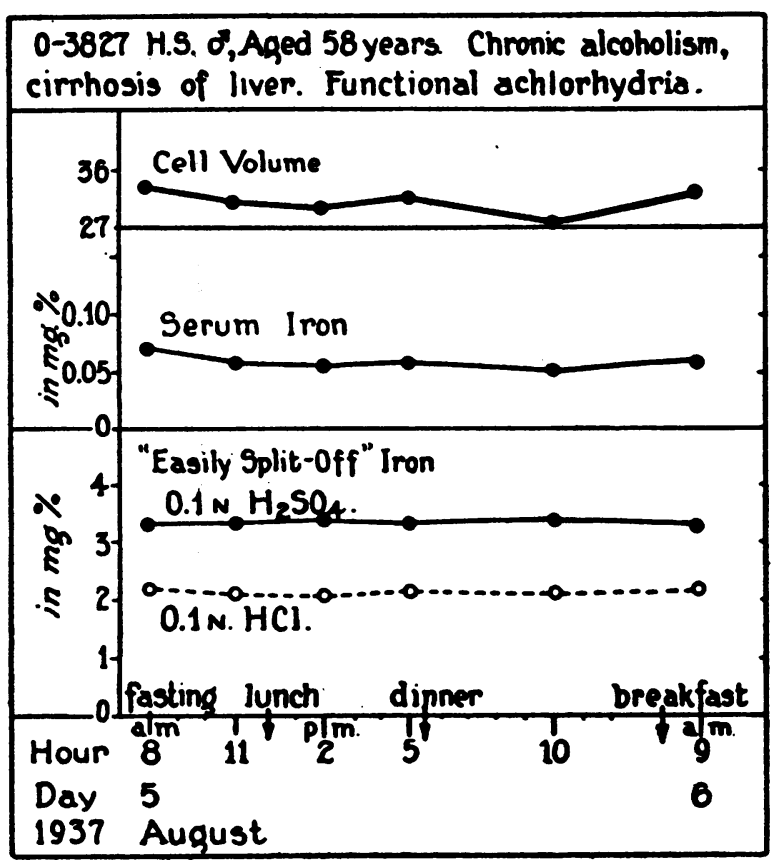

Fig. 5. Variations in Serum and "Easily Splitoff" Iron during a 24-hour Period in a Patient with Functional ACHLORHYDRIA
Variations in the blood iron fractions of normal female subjects during 6 months of observation

During the time this study was being made, 16 " normal" Freshman college women were subjecting themselves, as a part of another project, to complete finger blood counts biweekly. These young women permitted venipunctures to be done at intervals of 4 weeks for 6 months in order that serum and "easily split-off" iron determinations might likewise be obtained. They reported to the laboratory between 8 and 9 o'clock without breakfast on the same morning of each week that blood was to be drawn. Minimum and maximum values for the various data accumulated are summarized in Table $I$. The variations of approximately one million in total red cells were no greater than those observed by Doan and Zerfas (15) when consecutive counts at intervals of 15 minutes over a period of hours were obtained on normal subjects. Hemoglobin and packed cell volume changes closely paralleled those for the red cells.

The lowest serum iron value observed during

TABLE I

Extremes of variation in serum and "easily split-off" iron observed during six months of study in sixteen normal college women

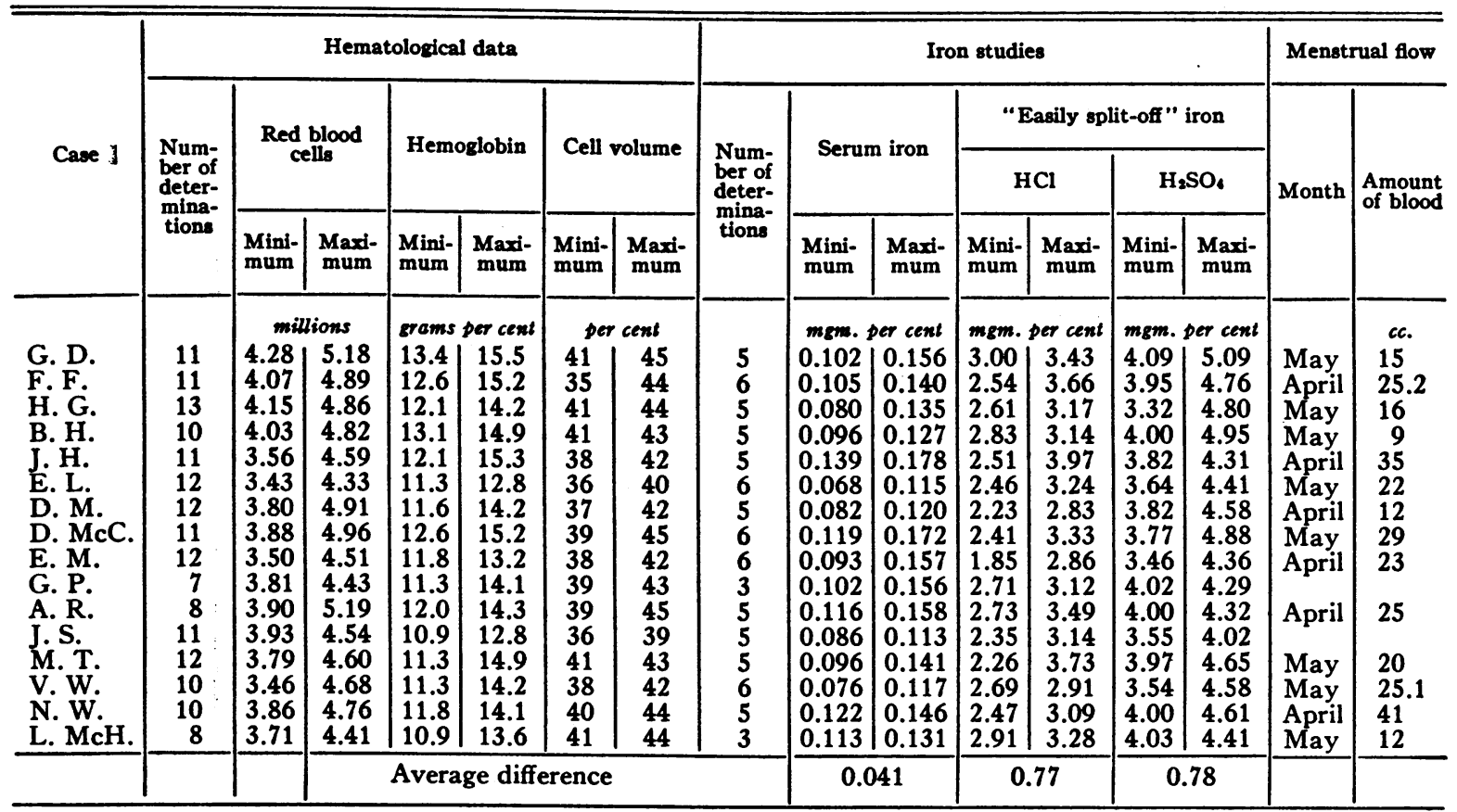


E.L. $\%$, Aged 18 years.

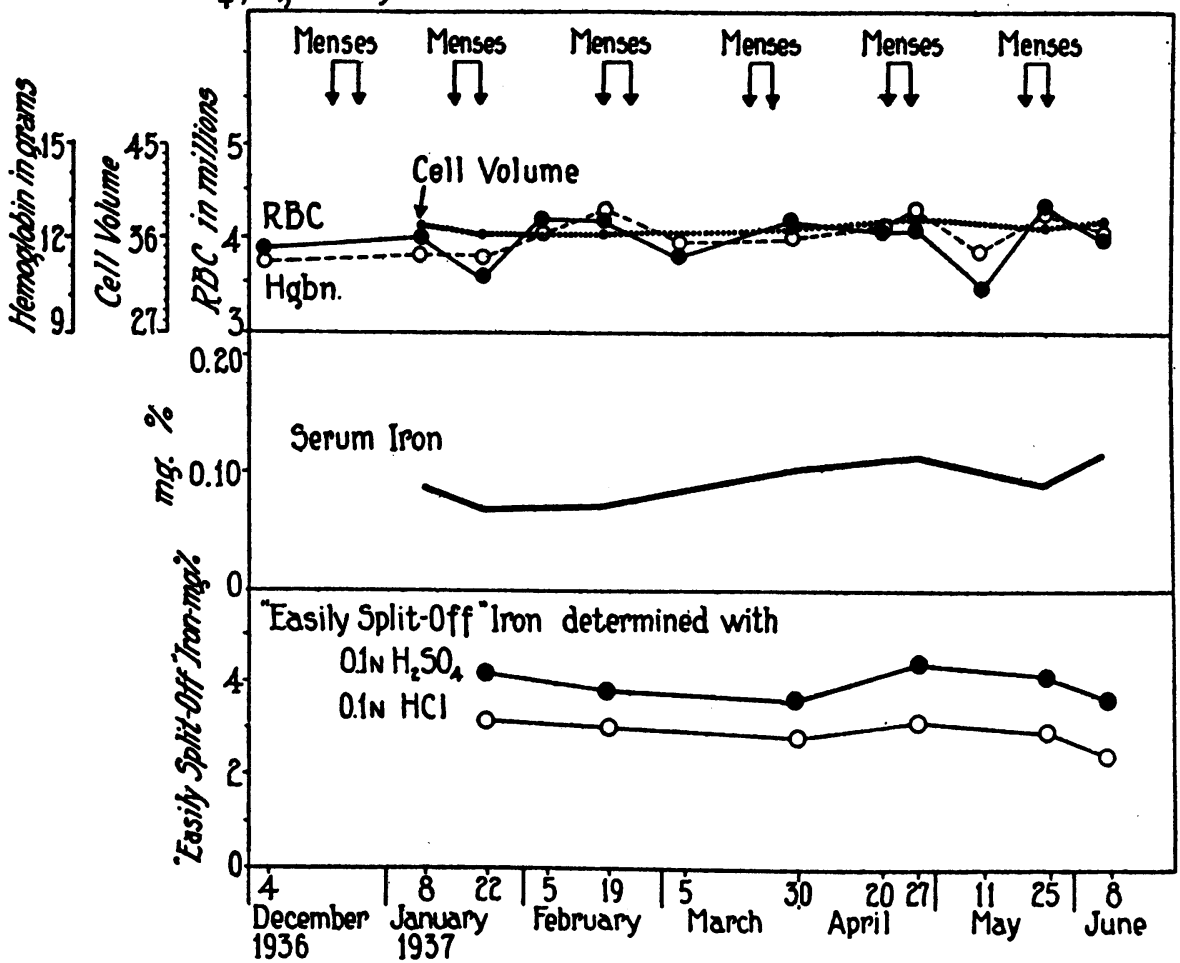

Fig. 6. Relative Constancy of Serum and "Easily Split-Off" Iron in a Normal Subject During Five Months of Observation

\section{J.9. q.Aqed 17 yeaps}

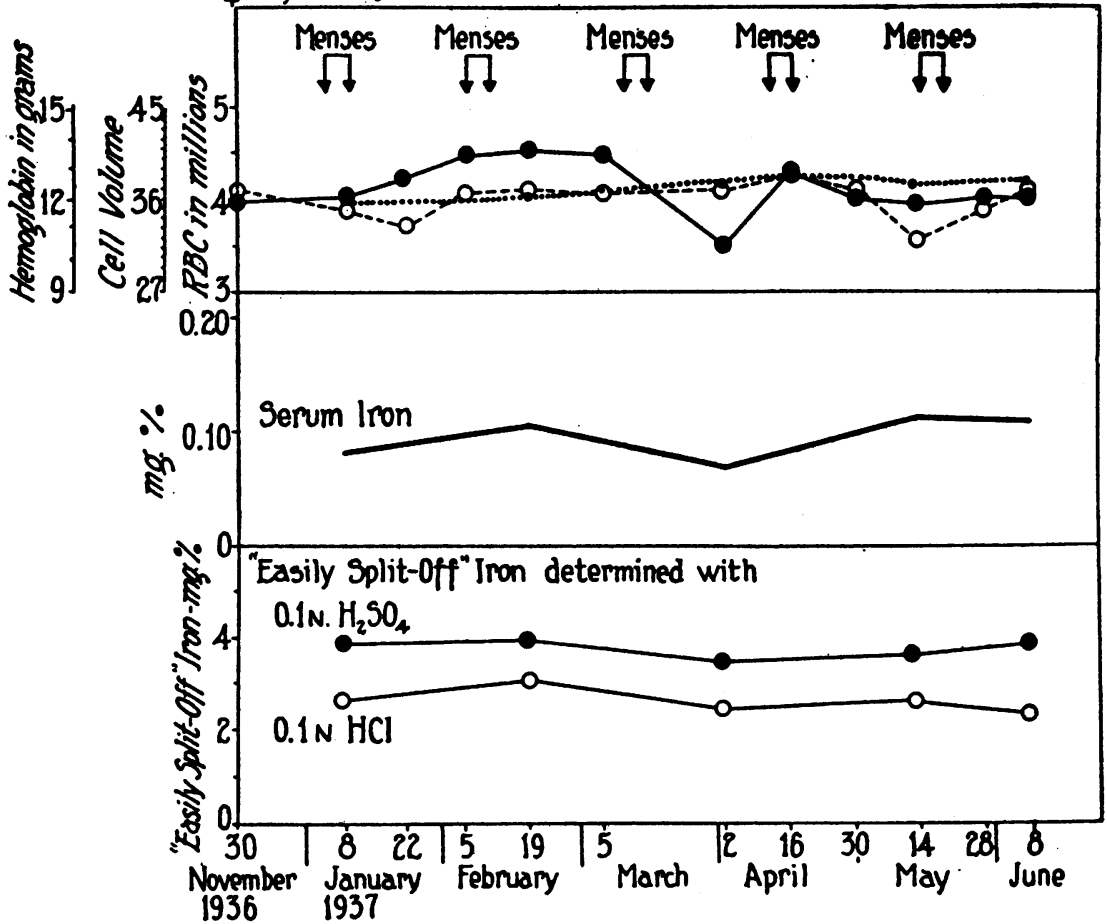

Fig. 7. Relative Constancy of Serum and "Easily Split-Off" Iron in a Normat Subject During Five Months of Observation 
the whole study was $0.068 \mathrm{mgm}$. per cent; the highest $0.178 \mathrm{mgm}$. per cent; differences between minimum and maximum serum iron values for individual subjects ranged from 0.018 to 0.064 mgm. per cent and averaged $0.041 \mathrm{mgm}$. per cent for the group. Figures 6 and 7 contain graphic representations of the data from two representative cases and serve to show that the changes were previously reported (1). The differences in individual cases ranged from 0.22 to $1.47 \mathrm{mgm}$. per cent for $\mathrm{HCl}$ and from 0.27 to $1.48 \mathrm{mgm}$. per cent for $\mathrm{H}_{2} \mathrm{SO}_{4}$; the average variation was 0.77 mgm. per cent.

These observations required that $50 \mathrm{cc}$. of blood be withdrawn from each of the subjects once every four weeks. This blood loss was not

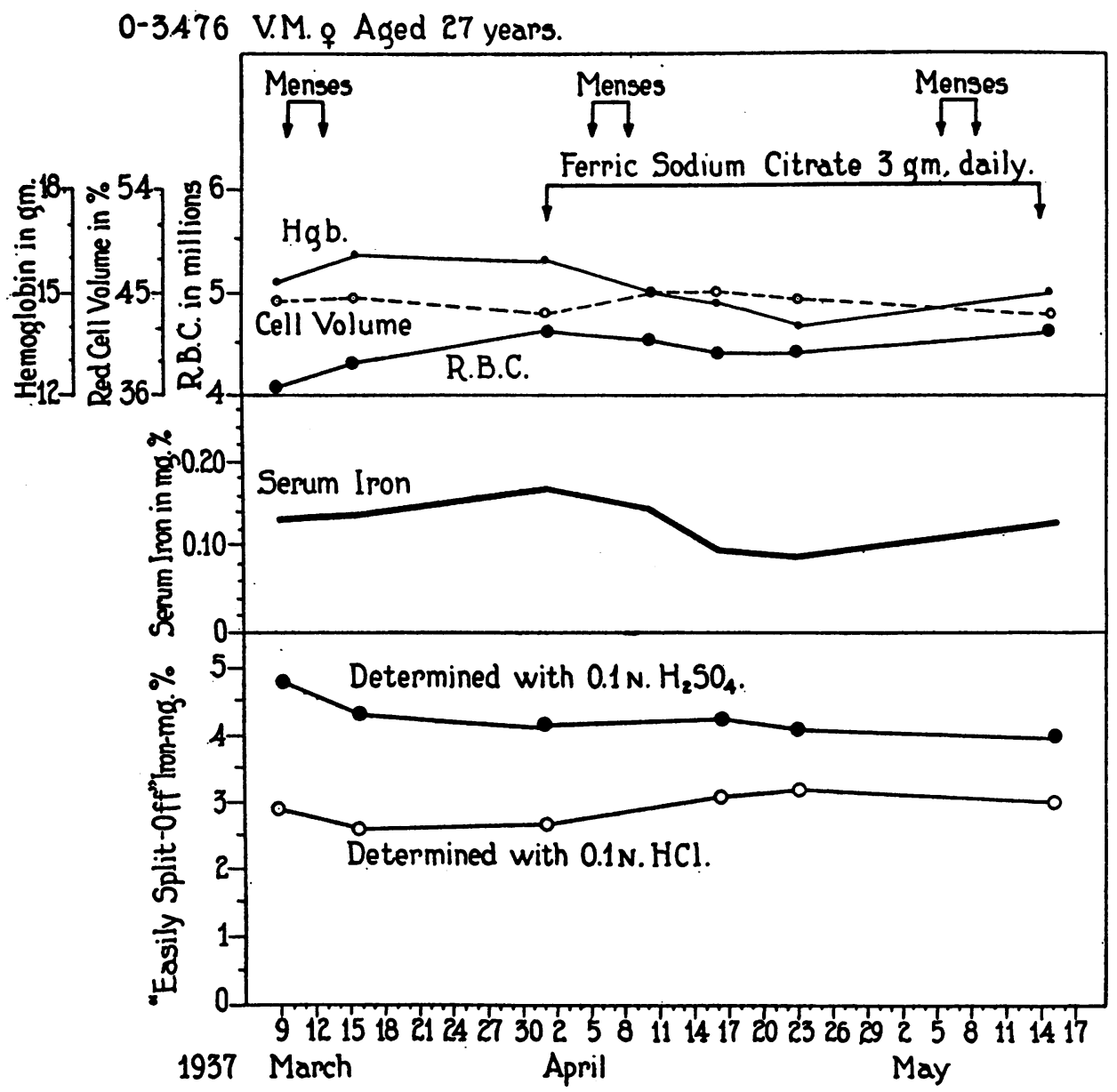

Fig. 8. Effect of the Oral Administration of Ferric Sodiux Citrate on the Blood Iron Relationships in a Normal Female Subject.

oscillating in type and had no persistent directional characteristics. No correlation with phases of the menstrual cycle could be made.

The over-all minimum and maximum values for the whole series of determinations were 1.85 and 3.97 mgm. per cent for "easily split-off" blood iron determined with $0.1 \mathrm{~N} \mathrm{HCl}$, and 3.32 and $5.09 \mathrm{mgm}$. per cent for those made with 0.1 N $\mathrm{H}_{2} \mathrm{SO}_{4}$. These limits agree well with those thought to be sufficient to embarrass the iron reserves of these healthy young women, but in order to check more carefully on the amounts of iron being lost by hemorrhage, determinations of the menstrual blood flow were made. Used perineal pads were placed immediately into glass jars which contained $0.1 \mathrm{~N} \mathrm{HCl}$. Attempts were made to avoid loss at times of micturition and defecation. When each period was complete, the 
pads were extracted repeatedly with additional amounts of $0.1 \mathrm{~N} \mathrm{HCl}$. Seven to 10 liters of the dilute acid were usually used for one set of menstrual pads. An aliquot portion of the extract was taken for digestion and the determination of iron. A number of unused pads was extracted in a similar manner in order that correction might be made for the iron present in them. For the purpose of calculating the maximum menstrual
Effect of specific antianemic therapy on the blood iron fractions of hematologically equilibrated individuals

It is of theoretical interest to know whether it is possible to increase the serum iron level of normal individuals by giving them iron in therapeutic amounts so as to saturate their storage depots. Accordingly, various iron salts-ferrous sulfate,

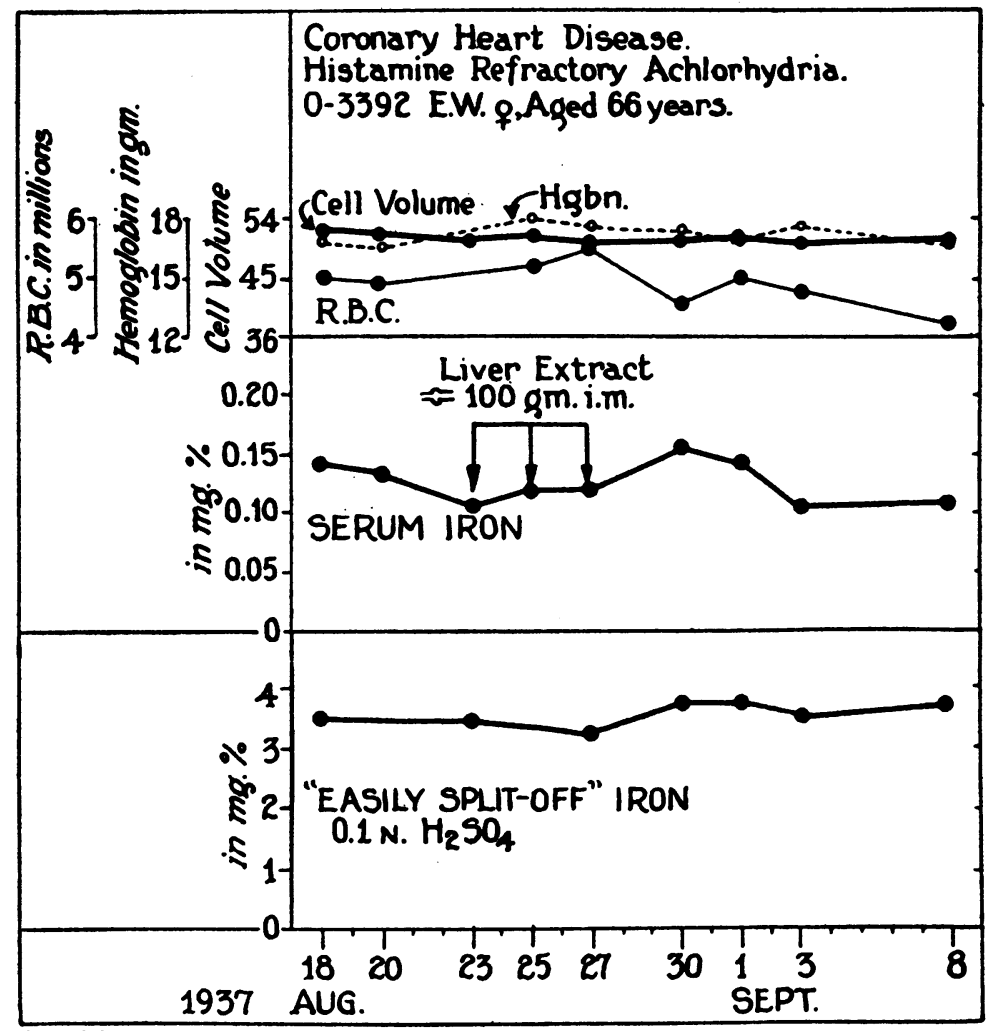

Fig. 9. Effect of Parenterally Administered Liver Extract on Blood Iron Relationships in a Subject with Normal Blood Picture

flow, it was assumed that all the iron had been discharged as hemoglobin. Even with this assumption, the loss in terms of volume of blood (calculated on the basis of the subject's hemoglobin level) ranged only from 9 to $41 \mathrm{cc}$. It was not possible to correlate the serum iron or hemoglobin levels with the quantity of menstrual flow; that is, girls with the largest menstrual loss did not necessarily have the lowest serum iron and hemoglobin values. ferrous carbonate, iron pyrophosphate, ferric sodium citrate, ferric ammonium citrate-were taken by a number of healthy adult subjects in ordinary therapeutic doses for periods of time which varied from 4 to 8 weeks. In no instance was any significant change in either serum or " easily split-off" blood iron values noted. The data from one of these observations are graphically recorded in Figure 8.

Parenteral injection of liver extract likewise 
failed to influence the level of the blood iron fractions in subjects with normal blood pictures. One of the patients on whom these negative results were obtained is of interest in that he had a histamine refractory achlorhydria (Figure 9).

\section{DISCUSSION}

When one considers that serum or transport iron must at all times be in physiological equilibrium with the amount of the metal being absorbed from the gastro-intestinal tract, being utilized by the bone marrow for hemoglobin synthesis, being excreted, being added to, or withdrawn from the storage depots, and that being thrown into the blood stream as the hemoglobin from destroyed red cells is broken down to bile pigment, then the fluctuations of 10 to 65 micrograms per cent observed in the normal subjects studied in this investigation are not surprising. These changes within the normal zonal range were oscillating in nature and had none of the specific directional characteristics which are so typical of those changes which invariably have been found to result from disturbances of the erythrocytogenic equilibrium $(2,3)$.

The failure of liver extract to influence serum iron levels of normal individuals was an expected finding, but the inability of orally administered iron to raise the fraction above normal levels is particularly interesting. The experiments of Fowler and Barer (16) and of Brock and Hunter (17) indicate that amounts of iron as great as 6 to 8.8 grams may be retained by the human subject during one month of ordinary therapeutic administration, amounts which are over twice the quantity of iron present in the circulating blood of an average adult male. If the equilibrium between serum and stored iron is purely physicochemical in nature, it would be reasonable to expect a decided increase in serum iron as the storage depots become more adequately supplied. Since such an increase did not occur during periods of 6 to 8 weeks of iron therapy, it is suggested that either: (1) a regulating mechanism, operative under normal conditions, controls the serum iron level, or (2) a portion of absorbed iron is deposited in tissues, possibly in skin, in a form which removes it temporarily at least from availability to the body economy.
As has already been stated, "easily split-off" iron is of less theoretical interest in any consideration of problems related to iron transportation because evidence has been presented which tends to show that it is derived from a compound formed as an intermediary stage in the breakdown of hemoglobin to bile pigment (12).

\section{CONCLUSIONS}

1. The color of ferric thiocyanate in iso-amyl alcohol, extracted from an acid $\left(\mathrm{H}_{2} \mathrm{SO}_{4}\right)$ aqueous solution was found to be:

(a) Practically constant for a period of an hour, when kept in a darkened room.

(b) Unchanged both in intensity and quality when the acid solution from which it was extracted varied in acidity from 2 to 4 normal.

(c) Directly proportional in intensity to the amount of iron present, at least within the range of 0.002 to $0.04 \mathrm{mgm}$. of iron per $10 \mathrm{cc}$. iso-amyl alcohol. This amount of iron corresponds, with the method used, to a variation of serum iron from 0.05 to $1.0 \mathrm{mgm}$. per cent.

2. Differences between minimum and maximum serum iron values in a given normal subject ranged within the daily cycle and during a 6month period, from 0.01 to $0.065 \mathrm{mgm}$. per cent. These changes were oscillating and distinctly not specifically directional in character.

3. Liver and iron medication to the normal subject did not effect any appreciable alteration in the serum iron level.

4. "Easily split-off" iron varied in the normal human adult as much as $1.48 \mathrm{mgm}$. per cent. This fluctuation was likewise oscillating in type and unrelated to liver and iron therapy when the latter was given. The physiological importance of this blood iron fraction has fairly definitely been divorced from the function of iron transportation.

\section{BIBLIOGRAPHY}

1. Moore, Carl V., Studies in iron transportation and metabolism, chemical methods and normal values for plasma iron and "easily split-off" blood iron. J. Clin. Invest., 1937, 16, 613. 
2. Moore, Carl V., and Doan, Chas. A., Mechanism of iron transportation: its significance in iron utilization in anemic states of varied etiology. J. Clin. Invest. (Proc.), 1936, 15, 455.

Moore, Carl V., Doan, Chas. A., and Arrowsmith, Wm. R., Studies in iron transportation and metabolism. II. The mechanism of iron transportation: its significance in iron utilization in anemic states of varied etiology. J. Clin. Invest., 1937, 16, 627.

3. Moore, Carl V., and Doan, Chas, A., Correlation of serum iron, bone marrow and blood cell changes following specific therapy in the macrocytic anemias. Arch. Path. (Proc.), 1937, 23, 738.

4. Heilmeyer, Ludwig, and Plötner, Kurt, Das Serumeisen und die Eisenmangelkrankheit. (Pathogenese, symptomologie und therapie.) Jena, Gustav Fischer; 1937.

5. Baer, P., Il ricambio del siero in diverse condizioni in rapporto al ricambio emoglobinico, Kongress bericht II des XVI Internationalen PhysiologenKongresses, 1938, p. 344.

6. Moore, Carl V., Arrowsmith, Wm. R., Welch, Jo, and Minnich, Virginia, Studies in iron transportation and metabolism. IV. Observations on the absorption of iron from the gastro-intestinal tract. J. Clin. Invest., 1939, 18, 553.

7. Hahn, P. F., Bale, W. F., Lawrence, E. O., and Whipple, G. H., Radioactive iron and its metabolism in anemia. J. A. M. A., 1938, 111, 2285.

8. Van Goidsenhoven, F., Hoet, J., and Lederer, J., Le fer Serique en clinique humaine. Revue belge Sc. méd., 1938, 10, 177.
9. Walker, B. S., The iron of human blood serum. J. Lab. and Clin. Med., 1938, 24, 308.

10. Locke, A., Main, E. R., and Rosbash, D. O., Copper and non-hemoglobinous iron contents of blood serum in disease. J. Clin. Invest., 1932, 11, 527.

11. Thoenes, Fritz, and Aschaffenburg, R., Der Eisenstoff wechsel des Wachsenden Organismus. Abh. aus der Kinderh. u. ihren Grenzgebieten, Verlag von S. Karger, Berlin, 1934, 35.

12. Barkan, G., and Schales, O., Chemischer Aufbau und Physiologische Bedeutung des "Leicht $\mathrm{Ab}$ spaltbaren" Bluteisens. 13. Mitteilung in der Reihe der Eisenstudien. Ztschr. f. Physiol. Chem., 1937, 248, 96.

13. Jenkins, C. E., and Thomson, M. L., Distribution of iron in blood. Brit. J. Exp. Path., 1937, 18, 175.

14. Heller, V. G., and Paul, H., Changes in cell volume produced by varying concentrations of different anticoagulants. J. Lab. and Clin. Med., 1934, 19, 777.

15. Doan, C. A., and Zerfas, L. G., Rhythmic range of white blood cells in human, pathological leucopenic and leucocytic states, with study of thirtytwo human bone marrows. J. Exp. Med., 1927, 46, 511.

16. Fowler, W. M., and Barer, A. P., Retention and utilization of orally administered iron. Arch. Int. Med., 1937, 59, 561.

17. Brock, J. F., and Hunter, D., Fate of large doses of iron administered by mouth. Quat. J. Med., 1937, $6,5$. 